\title{
Customer Satisfication towards Various Software Products Offered by Jemi Cluster
}

\author{
K. Jebilah Victoria, J Pavithra, A.Kamal
}

\begin{abstract}
Business extension comprises of different gathering of offers and limits; for the most part momentary intended to invigorate snappier and/or more noteworthy buy of a specific item by shoppers or the exchange. Deals advancement incorporates instruments for customer advancement (for instance tests, coupons, prizes, money discount, guarantees, shows, challenge); exchange advancement (for instance purchasing recompenses, free products, stock stipends, co-usable publicizing, promoting and show remittances, vendor deals challenges); and deals power advancement (for instance rewards, challenges, deals encourages).
\end{abstract}

As of late the idea of affirmation projects has gotten more prominent consideration among instructed individuals for getting advancements in their vocation and to overhaul their profile. E-Learning Companies., has been the market's driving player from time in giving preparing and affirmations to experts from crosswise over different businesses from everywhere throughout the world been it neighborhood or worldwide. E-Learning Companies is the unprejudiced and free outsider Conformance Assessment Body. Level

Keywords : E-Learning Companies, Customer Satisfaction

\section{INTRODUCTION}

The intern has completed the summer internship program at "D.P Motors -Authorised Dealer for Mahindra Two Wheelers. "Within organizations, customer satisfaction ratings can have powerful effects. They focus employees on the importance of fulfilling customers' expectations. Furthermore, when these ratings dip, they warn of problems that can affect sales and profitability. [1],[3],[5]

These metrics quantify an important dynamic. When a brand has loyal customers, it gains positive word-of-mouth marketing, which is both free and highly effective.". This internship helped the intern to understand the activities and works of sales and marketing Department's Personnel in a practical manner

Revised Manuscript Received on July 22, 2019.

K.Jebilah Victoria, Student,Department of MBA,Bharath institute of Higher Education \& Research,Tamilnadu,India,Email:kvictoria@gmail.com

Ms. J Pavithra Assistant Professor,Department of MBA,Bharath institute of Higher Ed,ucation \& Research,Tamilnadu, India, Email: pavithralect@yahoo.com

Dr.A.Kamal, Associate Professor ,Department of EEE,Bharath institute of Higher Education \& Research,Tamilnadu, India, Email: ak2_anvi@yahoo.co.in

\section{REVIEW OF LITERATURE:}

This plausibility concentrate authorized by the National Institute for Advanced Industrial Science and Technology in Japan (AIST) and bolstered by the Sustainable Consumption Unit (UNEP) gave a review of methodologies utilized in various orders for assessing shopper conduct. The investigation dissected the appropriateness of existing examination ideas, speculations, and apparatuses for assessing buyer fulfillment with item administration frameworks (PSS). It included discourse over their qualities/shortcomings. This paper introduces a short review of the examination.

\section{RESEARCH METHODOLOGY:}

\section{A. METHOD OF DALLECTION:}

\section{Essential DATA:}

Essential information is recently gathering the information for our motivation.

\section{Auxiliary DATA:}

Auxiliary information is as of now exits yet make some understanding of the exit datafor our motivation. [13], [15] ,[ 17]

\section{Testing SIZE:}

Test size number of the components to be incorporated of the investigation .deciding the example size is mind boggling and includes a few subjective and quantitative contemplations. [14],[ 16], [18]

\section{RESULTS}

$1.61 \%$ of individuals acknowledged, 39\% does not acknowledge so these announcement giving data for the greater part of the businesses specialist co-op for any real enterprises.

2.97\% of individuals all the procedure utilizing just mechanized framework yet just, $3 \%$ of individuals does not utilizing robotized just utilizing manual procedure. 
3. $50 \%$ of the respondents utilized completely mechanized framework to keep up the information.

4. $55 \%$ of the respondents remain unbiased about business forms year on year.

\section{5. $40 \%$ respondents says their profitability us high.}

6. $60 \%$ of the respondents feel their front office is completely computerized.

7. $10 \%$ of individuals needs online MIS, $90 \%$ does not needs online MIS. [25],[27],[29]

8. $60 \%$ of individuals got routinely alert from the framework.

9. $50 \%$ of the respondents state that their information is normally verified.

10. $40 \%$ of individuals acknowledged that the work power is diminished after robotization.

11. $60 \%$ of individuals acceptedthatthey burned through $2 \mathrm{~L}$ - 3L as their spending limit.

12. $40 \%$ of the respondents said that they will prescribe this framework to their companions.

13. $60 \%$ of individuals feel that the estimating system of the item is reasonable.

\section{SUGGESTIONS}

1. Providing client care administration every minute of every day.

2. Company can refresh more innovations (Automation) so as to hold their clients.

3. Sales people groups are critical to the association; organization can choose progressively proficient sales reps so as to get in to the commercial center.

4. Organization can make their entire framework into computerized.

5. Companies can viable valuing methodology for their item. [19],[21],[23]

\section{DISCUSSION}

A features of the examination on consumer loyalty towards the JEMI CLUSTER product $76 \%$ individuals like our item generally the Jemi Cluster item give little scale industries, $80 \%$ people acknowledged our item yet a few people give all the more better deals and administrations Inferred that $37.8 \%$ of individuals firmly concur respondence , 37.4\% organization individuals agree, $20.7 \%$ individuals respondence to fulfill after deals and administrations Find out breaking down table for the most part $62 \%$ the Jemi Cluster item give little scale Industries 17\%Company have an issue of Jemi Cluster product[20],[22], [24]

\section{REFERENCES}

1) BharthVajan R., Ramachandran S.,Psychographic dimensions of training,2016,International Journal of Pharmacy and Technology,V-8,I-4,P-23727-23729

2) Balakrishnan P., Bharthvajan R.,A study on human resource planning in hospitals in Chennai City,2014,International Journal of Applied Engineering Research,V-9,I-22,P-7503-7507

3) Priyadarsini P., Bharthvajan R.,Role of emotional intelligence training programme in reducing the stress of the nurses,2014,International Journal of Applied Engineering Research,V-9,I-22,P-7411-7421

4) Kerinab Beenu G., Bharthvajan R.,Empirical analysis on the cosmetic buying behavior of young women in South India,2014,International Journal of Applied Engineering Research,V-9,I-22,P-7361-7366

5) Balakrishnan P., Bharthvajan R.,Whistling in the wind,2014,International Journal of Applied Engineering Research,V-9,I-22,P-7586-7593

6) Krishnan B., Peter M.,Health hazards of Indian Bpo employee-an alarming issue,2014,International Journal of Applied Engineering Research,V-9,I-22,P-7336-7341

7) Kerinab Beenu G.H., Peter M.,Role of insurance in economic development,2014,International Journal of Applied Engineering Research,V-9,I-22,P-7532-7539

8) Balakrishnan P., Peter M., Priyadarsini P.,Efficiency of safety measures for wellbeing of employees in manufacturing industry,2014,International Journal of Applied Engineering Research,V-9,I-22,P-7376-7382

9) Anbarasi M., Praveen Kumar S.,Online sales promotions of herbal products and its effectiveness towards tanisha.com,2019,Indian Journal of Public Health Research and Development,V-10,I-1,P-195-200

10) Anbarasi M., Praveen Kumar S.,Various online marketing and promotions strategies to improve the validation towards the organic products in the pharmaceutical sectors,2019,Indian Journal of Public Health Research and Development,V-10,I-1,P-263-269

11) Loganathan R., Praveen Kumar S.,Grievance handling a key factor for solving issues of employees in an organization,2014,International Journal of Applied Engineering Research,V-9,I-22,P-7483-7491

12) Loganathan R., Praveen Kumar S.,Study on preference of private label brands in super and Hypermarkets,2014,International Journal of Applied Engineering Research,V-9,I-22,P-7327-7335

13) Smitha M., Praveen Kumar S.,Understanding stress and its managementamong the nurses in Chennai city,2014,International Journal of Applied Engineering Research,V-9,I-22,P-7560-7565

14) Kerinab Beenu G.H., Praveen Kumar S.,A study on the investment behavior of Chennai investors in mutual fund schemes,2014,International Journal of Applied Engineering Research,V-9,I-22,P-7520-7525

15) Loganathan R., Praveen Kumar S.,Retention strategies key for organizational productivity,2014,International Journal of Applied Engineering Research,V-9,I-22,P-7443-7447

16) Pavithra J., Ganesan M., Brindha G.,State wise analysis of microfinance sector in India,2016,International Journal of Pharmacy and Technology,V-8,I-4,P-23417-23432

17) Pavithra J., Ganesan M.,A comparative study on microfinance in India and abroad,2016,International Journal of Applied Business and Economic Research,V-14,I-8,P-5471-5476

18) Pavithra J., Ganesan M.,A study on awareness and impact of micro-financial schemes,2016,International Journal of Applied Business and Economic Research,V-14,I-8,P-5449-5460

19) Senthilmurugan P., Pavithra J.,Consumer preference towards organised retailing with reference to Big Bazaar,2014,International Journal of Applied Engineering Research,V-9,I-22,P-7469-7475

20) Senthilmurugan P., Pavithra J.,Implication of social media marketing in growing healthcare industry,2014,International Journal of Applied Engineering Research,V-9,I-22,P-7448-7456

21) Loganathan R., Pavithra J.,Consumer perception towards private label brand over other brands in super markets and hypermarkets,2014,International Journal of Applied Engineering Research, V-9,I-22,P-7355-7360

22) Kerinab Beenu G., Pavithra J.,Tradeâ€"off between liquidity and profitability in logistics industry,2014,International Journal of Applied Engineering Research,V-9,I-22,P-7398-7401

23) Kerinab Beenu G., Pavithra J.,A study on the prospective consumerâ€ $€^{\mathrm{TM}_{S}}$ perception towards utility cars in Chennai city,2014,International Journal of Applied Engineering Research,V-9,I-22,P-7526-7531

24) Pavithra J., Dilli Babu P., Ambuli T.V.,A study on budgetary control at Maruti Service Masters, 
Chennai,2014,International Journal of Applied Business and Economic Research,V-12,I-2,P-151-161

25) Pavithra J., Dilli Babu P., Ambuli T.V.,A study on customer satisfaction of retro Garments Pvt Ltd, Chennai,2014,International Journal of Applied Business and Economic Research,V-12,I-2,P-381-391

26) Kerinab Beenu G.H., Pavithra J., Senthilmurugan P.,A study on the influence of promotional activities for TATA ARIA among consumers in Chennai,2014,International Journal of Applied Engineering Research,V-9,I-22,P-7572-7578

27) Vijayaragavan S.P.,An investigative expert that's general FBG sensors,International Journal of Mechanical Engineering and Technology,V-8,I-8,PP-1500-1505,Y-2017

28) Vijayaragavan S.P.,Equalization routing protocol for Wi-Fi sensor strategy,International Journal of Mechanical Engineering and Technology,V-8,I-8,PP-1662-1666,Y-2017

29) Karthik B., Kiran Kumar T.V.U., Vijayaragavan P., Bharath Kumaran E.,Design of a digital PLL using $0.35 \hat{1}^{1} 1 / 4 \mathrm{~m}$ CMOS technology,Middle - East Journal of Scientific Research,V-18,I-12,PP-1803-1806,Y-2013

30) Kanniga E., Selvaramarathnam K., Sundararajan M.,Kandigital bike operating system,Middle - East Journal of Scientific Research,V

31) Jasmin M., Vigneshwaran T., Beulah Hemalatha S.,Design of power aware on chip embedded memory based FSM encoding in FPGA,International Journal of Applied Engineering Research,V-10,I-2,PP-4487-4496,Y-2015

32) Jasmin M.,Optimization techniques for low power VLSI circuits,Middle East Journal of Scientific Research,V-20,I-9,PP-1082-1087,Y-2014

33) Jasmin M., Vigneswaran T.,Fuzzy controller for error control of on - Chip communication,2017 International Conference on Algorithms, Methodology, Models and Applications in Emerging Technologies, ICAMMAET 2017,V-2017-January,I-,PP-1-5,Y-2017

\section{AUTHORS PROFILE}

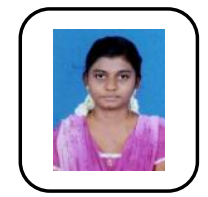

K.Jebilah Victoria, Student,Department of MBA,Bharath institute of Higher Education \& Research,Tamilnadu,India,Email:kvictoria@gmail.com

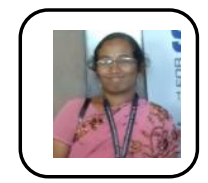

Ms. J Pavithra, Assistant Professor ,Department of MBA,Bharath institute of Higher Education \& Research,Tamilnadu, India,

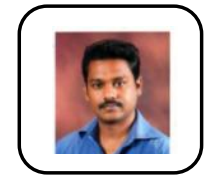

Third Author, Associate Professor ,Department of EEE,Bharath institute of Higher Education \& Research,Tamilnadu, India, Email: ak2_anvi@yahoo.co.in 